\title{
Oral mucosa transplantation may improve tear film osmolarity in dogs with keratoconjunctivitis sicca - a preliminary study
}

\author{
[Transplante da mucosa oral na melhoria da osmolaridade do filme lacrimal em cães com \\ ceratoconjuntivite seca - estudo preliminar] \\ F.L.C. Brito ${ }^{(1)}$, A. Kuner ${ }^{(1)}$, J.N. Voitena ${ }^{(D)}$, T.O.C. Marinho ${ }^{(D)}$ \\ Faculdade Qualittas, São Paulo, SP, Brasil
}

\begin{abstract}
The objective of this study was to evaluate the use of cyclosporine $1 \%$ alone or associated with oral mucosa transplantation (OMT) in dogs with dry keratoconjunctivitis (KCS). Schirmer Tear Test (STT-1) and Tear Film Osmolarity (TFO) were measured in both eyes of 30 adult dogs (before and 45 days after treatment. The animals were divided into three groups (10 dogs for group): control (normal dogs), group I (GI, treated with 1\% cyclosporine alone), and group II (GII, treated with $1 \%$ cyclosporine and OMT). All STT-1 and TFO values were subjected to the Shapiro-Wilk normality test, and all were normally distributed. STT-1 and TFO values before and after treatment were subjected to the T-Student Test. The STT-1 and TFO values of the right eye were subjected to Repeated Measures ANOVA followed by a Tukey Test for comparison between groups I and II. Means with a value of $\mathrm{p} \leq 0.05$ were considered significant. There was a decreased osmolarity in both groups after treatment. Mean osmolarity in GII $(322.60 \pm 16.56 \mathrm{mOsm} / \mathrm{L})$ was significantly lower than GI $(336.40 \pm 5.66$ $\mathrm{mOsm} / \mathrm{L}$ ). The OMT associated with cyclosporine $1 \%$ improved the osmolarity of the tear film in dogs with KCS with a seeming synergism between the clinical and surgical treatments.
\end{abstract}

Keywords: dry eye, Osmolarity, tear film, I-PEN ${ }^{\circledR}$ VET, Schirmer tear test

\section{RESUMO}

Avaliou-se o uso de ciclosporina 1\% isolada ou associada ao transplante de mucosa oral (TMO) em cães com ceratoconjuntivite seca (CCS). O teste lacrimal de Schirmer (TLS-1) e a osmolaridade do filme lacrimal (OFL) foram medidos em ambos os olhos, em 30 cães adultos, antes e 45 dias após o tratamento. Os animais foram divididos em três grupos (10 cães por grupo): controle (cães saudáveis), grupo I (GI, tratados apenas com ciclosporina 1\%) e grupo II (GII, tratados com 1\% de ciclosporina associada ao TMO). Todos os valores do TLS-1 e da OFL foram submetidos ao teste de normalidade Shapiro-Wilk, e todos foram distribuídos normalmente. Os valores de TLS-1 e OFT antes e depois do tratamento foram submetidos ao teste T-Student. Os valores TLS-1 e OFT do olho direito foram submetidos à ANOVA de medidas repetidas, seguida por um teste de Tukey para comparação entre os grupos I e II. Valor de P $\leq 0,05$ foi considerado significativo. Houve uma diminuição da osmolaridade em ambos os grupos após o tratamento. A osmolaridade média no GII $(322,60 \pm 16,56 \mathrm{mOsm} / \mathrm{L})$ foi significativamente inferior à no $\mathrm{GI}(336,40 \pm 5,66 \mathrm{mOsm} / \mathrm{L})$. O TMO associado à ciclosporina $1 \%$ melhorou a osmolaridade do filme lacrimal em cães com CCS, com uma sinergia aparente entre os tratamentos clínicos e cirúrgicos.

Palavras-chave: olho seco, osmolaridade, filme lacrimal, I-PEN ${ }^{\circledR}$ VET, teste lacrimal de Schirmer

\section{INTRODUCTION}

Keratoconjunctivitis sicca (KCS) is commonly diagnosed in canine patients and has an extensive list of potential etiologies, the most frequent cause being immune-mediated (Kaswan et al., 1998; Williams, 2008; Giuliano, 2013). Ultimately, KCS can lead to conjunctival and corneal desiccation, inflammation, pain, progressive corneal disease, and loss of vision (Giuliano, 2013).

The diagnosis of KCS is based primarily on clinical signs and the results obtained from ophthalmic examinations such as Schirmer's Tear Test-1 (STT-1), Rose Bengal test, Fluorescein Test, Tear Film Breakup Time (TFBUT) and more recently studied tear Osmolarity Test (Motta et al, 
2014; Williams, 2008; Williams and Buckingham, 2017).

Currently, hyperosmolarity evaluation is the gold standard for the diagnosis of dry eye in humans, in addition to being recognized as a proinflammatory stimulus in the development of the disease (Bron et al., 2017). The measurement of film lacrimal osmolarity has often been reported as the best method to diagnose dry eye and determine disease severity (Sullivan et al., 2010). Although it is considered an important diagnostic test in human medicine, (Lemp et al., 2011; Potvin et al., 2015) in veterinary medicine, the data are still incipient, and the test has not been implemented in clinical routine.

The medical treatment for KCS aims to restore lubrication on the eye surface and reduce inflammation. It is based on the topical use of calcineurin inhibitors with tear stimulating and immunomodulatory effects, such as cyclosporine A (CsA) and tacrolimus, for example (Moore et al., 2001). CsA is a neutral and lipophilic cyclic undecapeptide, being the first immunosuppressant to have a selective lymphoid ( $\mathrm{T}$ cell) effect. This effect on $\mathrm{T}$ cells is unique; it inhibits $\mathrm{T}$ cell proliferation without being cytotoxic in therapeutic concentrations (Schreiber and Crabtree, 1992).

Some surgical procedures can be used alone or associated with medical treatment (Angélico et al., 2011; Rosa et al., 2012; Castanho et al., 2013). The labial salivary glands transplant (LSGT) has proven to be a very efficient technique because it has a seromucous discharge that, together with its aqueous component, becomes very similar to the tear, aiming to stabilize the deficient tear film. Labial salivary gland transplant in dogs has been reported decreasing the inflammatory process of the ocular surface and consequently improving the clinical signs (discharge, blepharospasm, hyperemia conjunctival, corneal neovascularization) of KCS in dogs in the first 15 days after surgery in addition to the increase in STT-1 and TFBUT values (Angélico et al., 2011; Castanho et al., 2013).

In the study developed by Angelico et al. (2011) there was an increase in the STT-1 in 56\% of the patients and improvement of clinical signs in $93 \%$ of the eyes tested. Castanho et al. (2013) observed in their study little improvement in STT-1, but the clinical signs and TFBUT were satisfactory in the first 15 days after surgery.

This study aimed to compare the treatment of keratoconjunctivitis sicca in dogs with $1 \%$ cyclosporine alone or associated with OMT, by evaluating STT-1 and tear osmolarity.

\section{MATERIALS AND METHODS}

The bioethical care of animals involved in this study followed the guidelines set by the Association for Research in Vision and Ophthalmology - ARVO. This study included a total of 30 (60 eyes) Shih Tzu and Pug dogs, ten males and 20 females, aged 1-10 years, after full consent of their owners. For each group 5 Shih Tzu and 5 Pug dogs were used. The study was conducted at a private Veterinary Ophthalmology Service, so there was no ethics committee review. However, a consent form signed by the owner of the animal was used.

All animals underwent complete ophthalmological evaluation with slit-lamp biomicroscopy (SL-14 ${ }^{\circledR}$, Kowa Company, Tokyo, Japan), applanation tonometry (Reichert $\mathrm{Vet}^{\mathrm{TM}}$, USA), indirect binocular ophthalmoscopy (Eyetec, SP, Brazil), and specific tests such as STT-1 and osmolarity (Osm) before the experiment. All animals were evaluated in the same room at a temperature of $22^{\circ} \mathrm{C}$ and in the morning, between 8-11am

The animals were divided into three groups: control, group I (GI, treated with $1 \%$ cyclosporine), and group II (GII, treated with $1 \%$ cyclosporine associated with oral mucosa transplant - OMT). Both groups used 1\% cyclosporine, one drop twice a day and produced in the same pharmacy. The control group included only animals with STT-1 $\geq 15 \mathrm{~mm} / \mathrm{min}$, and GI and GII only animals with STT $-1 \leq 10 \mathrm{~mm} / \mathrm{min}$ with no apparent systemic diseases. The animals in the treated groups (GI and GII) were successively distributed into the groups: the first into GI, the second into GII, the third into GI, the fourth into GII, and so on until reaching ten animals in each group. The evaluations and procedures were performed in all groups in both eyes. The animals of group I and II were evaluated before being included in the study and after 45 days after of treatment. Healthy animals were evaluated only at the beginning of the study. 
Because the same evaluation was not performed 45 days later, the data was used only for verification after treatment, and no statistical comparison was made.

STT-1 was performed by inserting a standardized filter paper strip (Ophthalmos, São Paulo, Brazil) for measuring tear production. The edge of the strip, previously folded inside the plastic envelope, was inserted in the conjunctival fornix in the middle third of the lower eyelid for one minute. The wet part of the paper strip was read immediately after being removed from the eye, measuring strip wetness in $\mathrm{mm}$. Subsequently, the contralateral eye was tested.

Tear film osmolarity (TFO) was measured 30 minutes after rest period following STT-1, allowing ample time for tear turnover (Sebbag et al., 2019). The I-PEN ${ }^{\circledR}$ VET (I-Med Pharma, Canada) osmometry system was used, which includes single-use sensors to measure TFO by electrical impedance. The test was performed according to the manufacturer's specifications, using the sensor from the lacrimal meniscus near the side corner (Fig. 1). The mean of three consecutive repetitions was calculated to increase accuracy and repeatability. In cases where it was not possible to read (error message), the singleuse sensor was replaced, and the measurement was repeated.

The left eye and then the right eye were evaluated as standard for both STT-1 and TFO.

The animals in GII were submitted to preanesthetic medication with dexmedetomidine $(2 \mathrm{mcg} / \mathrm{kg})$, methadone $(0,2 \mathrm{mg} / \mathrm{kg})$, ketamine $(1 \mathrm{mg} / \mathrm{kg})$, induced with proporfol $(1-2 \mathrm{mg} / \mathrm{kg})$ and kept in the isofluoran with $100 \%$ oxygen. After antisepsis with povidine $10 \%$, of the internal surface of the upper and lower lips at $0.5 \mathrm{~cm}$ from the labial commissure, an elliptical cut of $1.0 \mathrm{~cm}$ $x 0.5 \mathrm{~cm}$ was performed with a 15 -blade scalpel up to the muscle layer. For lip fixation and eversion, a chalazion clamp was used. Subsequently, the graft was obtained by blunt dissection with an iris scissors. The surgical labial wound was repaired with a 4-0 synthetic absorbable suture (Vycril 40, Ethicon-Johnson \& Johnson Ltda). The graft was maintained in a sterile $0.9 \%$ saline solution until implantation. The recipient bed was prepared with a subconjunctival injection of $0.5 \mathrm{~mL}$ sterile saline solution in the dorsal bulbar conjunctiva, $5 \mathrm{~mm}$ from limbus, forming a bubble separating the conjunctiva from the underlying tissues to facilitate dissection. The conjunctival overlying this bubble was removed with iris scissors. The oral mucosa tissue was then positioned in the receiving bed with the glandular face in contact with the outer surface. The conjunctiva was sutured to the mucosa of the graft with single, separated sutures using non-absorbable 6-0 nylon thread $\left(\right.$ Nylon $^{\circledR}$; Ethicon-Johnson \& Johnson Ltda). The sequence of the surgical procedure is shown in Fig. 2. Postoperative medication included antimicrobial eye drops, containing ciprofloxacin $0.03 \%$ (Ciloxan ${ }^{\circledR}$; Alcon), one drop every six hours for seven days, and systemic nonsteroidal anti-inflammatory meloxicam (Maxicam $^{\circledR}$; Ourofino Pet), $0.1 \mathrm{mg} / \mathrm{kg}$ every 24 hours for three days.



Figure 1. Tear osmolarity measurements were performed using the I-PEN® VET osmometer in dogs. Osmolarity measurements were taken from the inferior palpebral conjunctiva. 


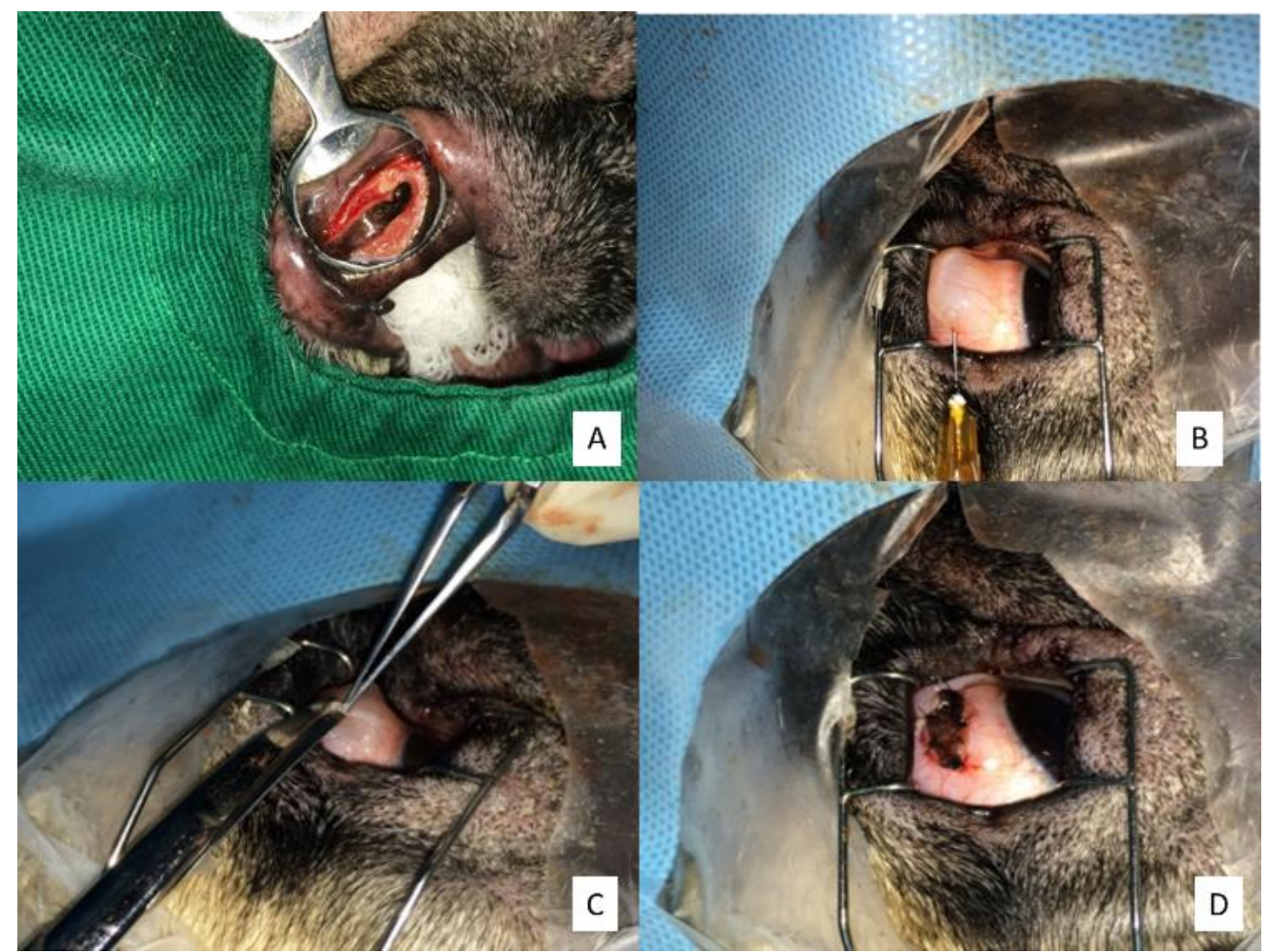

Figure 2. Surgical procedure for salivary labial gland transplantation. A. Upper and lower lips $0.5 \mathrm{~cm}$ away from the labial commissure, an elliptical cut of $1.0 \mathrm{~cm} \times 0.5 \mathrm{~cm}$ was performed up to the muscle layer. B. Application of saline solution and creation of a bubble to remove the subconjunctival tissue and preparation of the site for graft placement. C. Removal of subconjunctival tissue. D. Implant and attachment of the graft suture using simple isolated nylon 6-0 sutures.

The data from the control group were not used in the comparison between the groups but are being used to give an idea of the mean value of STT-1 and TFO in healthy dogs.

All STT-1 and TFO values were subjected to the Shapiro-Wilk normality test, and all were normally distributed. No significant difference was found between the right and left eyes, therefore, only data from the right eye of each dog was used for comparisons to avoid introducing a statistical bias, as the 2 eyes of 1 dog are more likely to be similar than two eyes from different dogs (Oliveira et al., 2019). STT-1 and TFO values before and after treatment were subjected to the T-Student Test. The STT-1 and TFO values of the right eye were subjected to Repeated Measures ANOVA followed by a Tukey test for comparison between groups I and II. Statistical analyses were performed using BioStat 5.0 for Windows. Means with a value of $p \leq 0.05$ were considered significant.

\section{RESULTS}

Mean \pm standard deviation (range) age of dogs in the control group was 5.9 \pm 2.77 years (1-10 years), group I and group II were $6.20 \pm 2.53$ years $(3-10$ years).

The first analytical approach of the study was to verify if there was a statistical difference between right and left eyes in the evaluation of STT-1 and TFO in each group. The general results are summarized in Table 1. In all groups evaluated, no significant difference ( $\mathrm{p} \geq 0.05$ ) was observed between right and left eyes. 
Table 1 . Mean \pm standard deviation of tear production and osmolarity in dogs healthy and with KCS, before and after treatment with cyclosporine $1 \%$ and cyclosporine $1 \%$ with oral mucosa transplant (OMT)

\begin{tabular}{lccccc} 
& & \multicolumn{2}{c}{ Group I } & \multicolumn{2}{c}{ Group II } \\
Test & Control & KCS & Cyclosporine 1\% & KCS & $\begin{array}{c}\text { Cyclosporine } 1 \% \\
+ \text { OMT }\end{array}$ \\
\hline STT-1 OD & $20.10 \pm 2.60$ & $5.00 \pm 2.54$ & $16.60 \pm 1.26$ & $4.70 \pm 3.16$ & $17.40 \pm 2.17$ \\
STT-1 OS & $20.10 \pm 2.77$ & $5.80 \pm 2.57$ & $16.90 \pm 1,60$ & $5.20 \pm 2,86$ & $17.70 \pm 2,79$ \\
Average & $20.10 \pm 2.61$ & $5.4 \pm 2.52$ & $16.75 \pm 1.40$ & $4.95 \pm 2.94$ & $17.55 \pm 2.43$ \\
\hline p-Value & 0.9079 & 0.4932 & 0.6707 & 0.6742 & 0.6742 \\
\hline Osm OD & $318.8 \pm 6.05$ & $352.5 \pm 6.67$ & $336.6 \pm 5.93$ & $349.5 \pm 5.23$ & $322.5 \pm 4.50$ \\
Osm OS & $321.5 \pm 4.95$ & $352.5 \pm 10.0$ & $335.5 \pm 5.69$ & $348 \pm 5.14$ & $321.5 \pm 3.83$ \\
Average & $320.15 \pm 5.55$ & $352.00 \pm 8.29$ & $336.40 \pm 5.66$ & $348.75 \pm 5.10$ & $322.60 \pm 16.56$ \\
\hline p-Value & 0.2883 & 0.8793 & 0.8793 & 0.4702 & 0.4702 \\
\hline STT-1: Schirmer Tear Test (mm/min); Osm: Osmolarity $(\mathrm{mOsm} / \mathrm{L})$ & &
\end{tabular}

Initially, the means between groups I and II before treatment were compared, and no significant difference was observed $(\mathrm{p}=0.397)$ in STT-1. When evaluating the before and after treatment, in both groups, a significant difference was observed in STT-1 values (GI and GII p<0.0001) (Figure

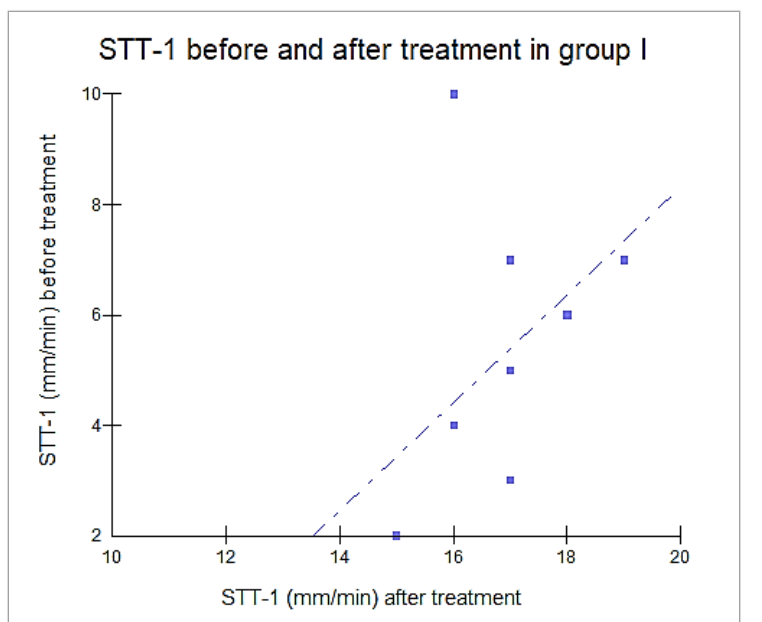

3 ). The analysis of the means of the two treatment groups, i.e., $1 \%$ cyclosporine $(16.75 \pm 1.40$ $\mathrm{mm} / \mathrm{min})$ and associated with OMT $(17.55 \pm 2.43$ $\mathrm{mm} / \mathrm{min}$ showed no statistical difference $(\mathrm{p}=$ 1.060). The STT-1 results are summarized in Fig. 3.

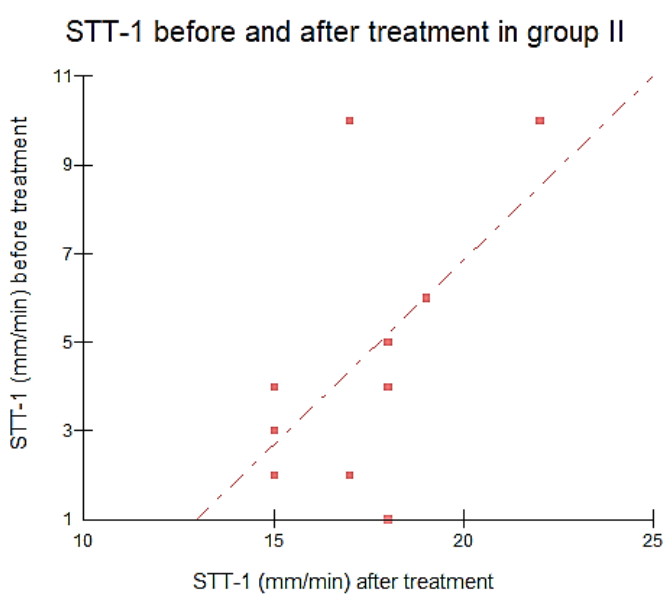

Figure 3. Scatter plot of Schirmer's Tear Test values before and after treatment with cyclosporine $1 \%$ and cyclosporine + OMT. Tukey Test.

The random distribution of patients with dry eye has also been confirmed for osmolarity. Comparing the means of GI $(352.00 \pm 8.29 \mathrm{mOsm} / \mathrm{L})$ and GII $(348.75 \pm 5.10 \mathrm{mOsm} / \mathrm{L})$, no statistical difference $(\mathrm{p}=1.681)$.

In the evaluation of the mean TFO before $(352.5 \pm 10.0 \mathrm{mOsm} / \mathrm{L})$ and after $(336.6 \pm 5.93 \mathrm{mOsm} / \mathrm{L})$ treatment in GI, a significant decrease $(\mathrm{p}<0.0001)$ in osmolarity values was observed. The same behavior of the data, before $(349.5 \pm 5.23 \mathrm{mOsm} / \mathrm{L})$ and after $(322.5 \pm 4.50 \mathrm{mOsm} / \mathrm{L})$, was verified in GII $(\mathrm{p}<0.0001)$. The comparison between the mean GI $(336.40 \pm 5.66 \mathrm{mOsm} / \mathrm{L})$ and the mean GII $(322.60 \pm 16.56 \mathrm{mOsm} / \mathrm{L})$, both after treatment, showed a significant difference favorable to GII $(p<0.0001)$. The graphical representation of the means is summarized in Fig. 4. 

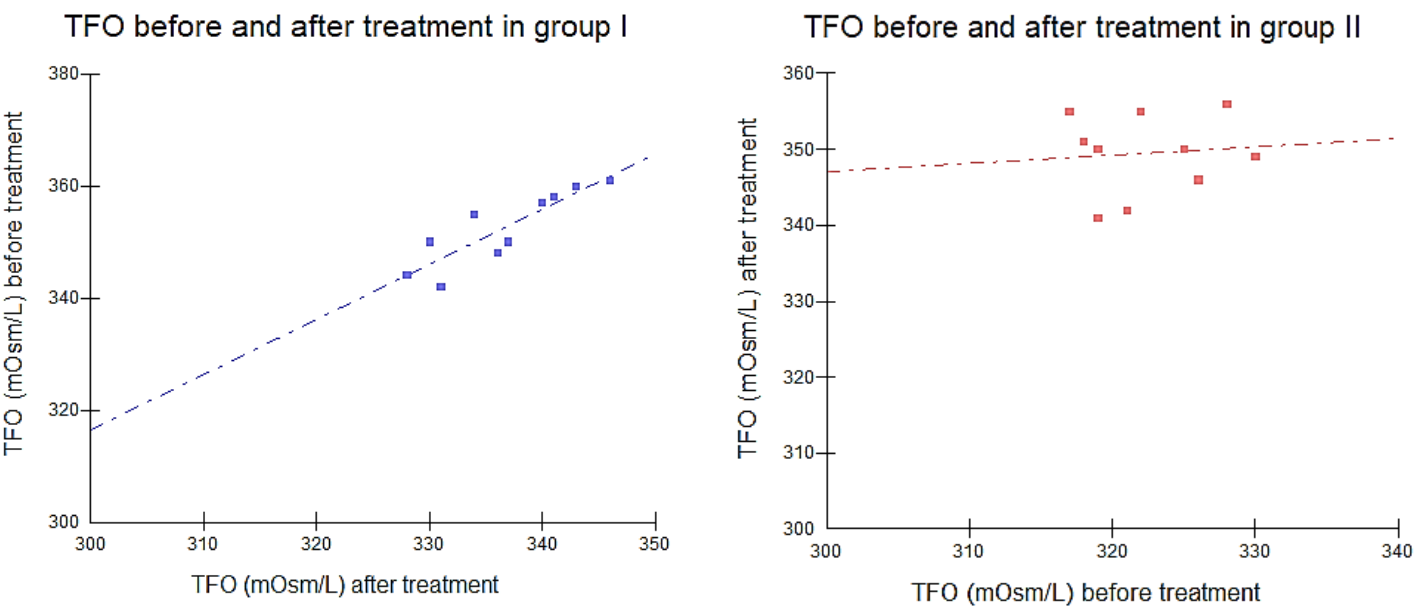

Figure 4. Scatter plot of tear film osmolarity values before and after treatment with cyclosporine $1 \%$ and cyclosporine + OMT. Tukey Test

\section{DISCUSSION}

This study describes the results of KCS treatment in dogs with $1 \%$ cyclosporine alone or associated with OMT. The use of $1 \%$ cyclosporine proved to be effective in the treatment of dry eye in dogs, increasing STT-1 values to the normal range, as well as decreasing TFO values. However, TFO values were still slightly above the normal range when compared to the control group. A recent study (Lamkin et al., 2020) shows the basal and reflex osmolarity value used I-PEN VET in normal dogs. The mean osmolarity of the right and left eyes before topical anesthetic instillation (Osm-1) was $319.79 \pm 22.92 \mathrm{mOsm} / \mathrm{L}$ and $317.32 \pm 20.59 \mathrm{mOsm} / \mathrm{L}$, respectively.

The administration of CsA in the treatment of the dry eye will act by interrupting the destruction of the lacrimal gland by the patient's own immune system, inhibiting the T-helper cells, diminishing the inflammatory process and, restoring the normal lacrimal function and secretion of the aqueous fraction of the tear film (Dodi, 2015) CsA also improves mucin production in conjunctival goblet cells, consequently improving the stability of the tear film, which is recommended in cases of loss of lacrimal quality (Moore et al., 2001. However, despite this effect, it is common to see mild ocular discharge and corneal vascularization in dogs even under CsA treatment, especially in brachycephalic breeds, possibly due to the low quality of the tear film without some of the substances necessary, such as mucin, mineral salts, proteins, and enzymes, for ocular surface homeostasis. Currently, the effectiveness of CsA in the treatment of dry eyes of immune etiology in dogs is clear and unquestionable (Moore et al., 2001). However, its effects on the ocular surface of dogs with KCS remains understudied (Lee $e t$ al., 2018).

Moreover, clinical improvement of severe dry eye has been reported in the human literature after LSGT (Soares and Franca, 2005). LSGT to the conjunctival fornix is an easy procedure, accessible to any ophthalmology surgeon (Soares and Franca, 2005). In veterinary medicine, the data differ between studies regarding the presence of labial salivary glands in the oral mucosa of dogs. Some studies show that labial salivary glands in dogs have histological characteristics similar to tear glands, since both are mixed glands, i.e., they produce serous and mucous secretions (Dellmann and Brown, 1982). The histochemical evaluation of small salivary glands was positive in Periodic acid-Schiff stain (PAS), producing neutral glycoconjugate secretions. They were also positive in Alcian blue staining demonstrating that they secrete acidic and sulfated glycoconjugates, i.e., glycosaminoglycans (Galvão et al., 2016). Meanwhile, in another study, labial salivary glands were not observed (Cherry et al., 2018) Despite the histological divergence, clinical studies showed benefits in using SLGT to treat KCS in dogs (Angélico et al., 2011; Castanho et al., 2013). In one of the studies, mucopurulent secretion, conjunctival hyperemia and blepharospasm diminished in all cases, as well as stabilization of preexistent lesion with important. 
The mucosal transplantation resulted on break-up time (BUT) tests improvement but no significant changes on Schirmer tests (Castanho et al., 2013). An improved BUT may indicate surfactant production by the glands, thus improving the quality of the tear film. In the other study, the reduction of symptoms was observed in the second week of the postoperative period, translated by the recovery of the brightness of the ocular surface accompanied by a great reduction of the irritative picture, photophobia and blepharospasm. In our study, the mean STT-1 values of animals receiving salivary gland transplants compared to animals treated exclusively with CsA showed no significant difference $(\mathrm{p}=0.3464)$, which was expected considering that the objective of SLGT is to restore the mucin layer. However, the literature reports increased STT-1 (Angélico et al., 2011) in dogs with KCS treated exclusively with SLGT.

In our study, there was a marked decrease in the mean osmolarity of GII, with values similar to the control group and below the mean of the animals treated exclusively with CsA. The lubrication of the ocular surface produced by OMT treatment associated with cyclosporine proved to be efficient, well-tolerated, and constant.

Currently, osmolarity is the gold standard in the diagnosis of dry eye in humans (Bron et al., 2017). In veterinary medicine, there are few studies using this methodology to assess tear film (Sebbag et al., 2015, 2017). These studies present highly variable normal values $(227-400 \mathrm{mOsm} / \mathrm{L})$, with a mean value ranging from $337-356 \mathrm{mOsm} / \mathrm{L}$. However, all of them were performed using equipment different from the one used in this study. Using I-PEN VET, the mean was $320.15 \pm 5.55 \mathrm{mOsm} / \mathrm{L}$ in healthy dogs. Recently, a study conducted with the same equipment (Lamkin et al., 2020) showed a mean of $318.55 \pm 20.82 \mathrm{mOsm} / \mathrm{L}$ in healthy dogs, which is very similar to the result obtained in our study.

As for the use of I-PEN VET in dogs with KCS, no data were found in the current literature to compare with the results of our study. Therefore, all comparative analyses were performed with studies using different equipment, which may justify some differences. Our study shows a significantly increased osmolarity $(\mathrm{p}<0.0001)$ in dogs with KCS (Table 1). In a recent paper, the evaluation of healthy and atopic dogs, the mean tear film osmolarity showed a significant statistical difference, with mean values of $320.8 \pm 9.6 \mathrm{mOsm} / \mathrm{L}$ and $340.3 \pm 21.6 \mathrm{mOsm} / \mathrm{L}$, respectively (Lourenço et al., 2017). The mean osmolarity obtained in the present study also corroborates with these data, although different equipment was used. An experimental study in rats with dry eye induced by toxicity reported an increased TFO compared to the control group using TearLab (Marques et al., 2015). A study comparing normal dogs to dogs with KCS before treatment showed a significantly higher mean tear osmolarity in normal dogs $(337.4 \pm 6.2 \mathrm{mOsm} / \mathrm{L})$ than in dogs with KCS before treatment (306.2 $\pm 18.0 \mathrm{mOsm} / \mathrm{L} ; \mathrm{p}<0.0001)$, but not after using $2 \%$ cyclosporine $(330.5 \pm 13.7 \mathrm{mOsm} / \mathrm{L}$; $\mathrm{p}=1.00$ ) (Sebbag et al., 2017), completely diverging from the data obtained in our study. Nevertheless, this is the only study of which the author is aware that dogs with KCS present. Although there is no standardized protocol in the literature for performing the osmolarity test using the I-PEN VET, and the difference in values may be related to "measurement error", measuring 3 consecutive times may be a way to minimize this "error".

The limitations of our study include the not controlled humidity and temperature in the examination room, which could interfere with the results (Yoon et al., 2020). Nevertheless, all animals were examined in the same room with air conditioning at the same temperature $\left(22^{\circ} \mathrm{C}\right)$, minimizing interferences. In addition, I-PEN VET showed an error in the reading sensor when in contact with eye surface tissue, thus prolonging the sampling time in certain animals, since sampling continued until three readings were obtained. A similar situation was observed in a study using the same apparatus (Lamkin et al., 2020). Despite the extended time, this did not prove to distort the osmolarity readings or to be a determining factor. Another limitation in our study is due to the lack of verification of STT-1 and TFO values of the control group after 45 days. We could have had a higher reproducibility of the TFO through the I-PEN VET. Because of this, the control group was used only as informative data of patients without dry eye, however, it was not used in the statistical comparison analyses.

Hyperosmolarity is reported as an important factor in pathophysiology of dry eye, both as an initial and perpetuating sign of the disease, as it 
catalyzes inflammation and decreases subsequent tear secretion. The results obtained in our study show a clinical benefit of using OMT associated with $1 \%$ cyclosporine in patients with KCS. Corroborating the information described above, the data obtained in this study shows the feasibility of evaluating TFO in clinical practice, which is easy to use in dogs and needs minimum animal restraint without sedation. Moreover, the lubrication of the ocular surface by salivary secretion from the transplant associated with cyclosporine $1 \%$ seems effective in improving the ocular surface surfactant. However, future studies correlating osmolarity with clinical signs in dogs with dry eye undergoing OMT should be explored to assess the full benefit of OMT treatment.

\section{REFERENCES}

ANGÉLICO, G.T.; RANZANI, J.J.T.; BRANDÃO, C.V.S. et al. Transplante de glândulas salivares menores no tratamento da ceratoconjuntivite seca em cães. Arq. Bras. Med. Vet. Zootec., v.63, p.1087-1092, 2011.

BRON, A.J.; PAIVA, C.S.; CHAUHAN, S.K. et al. TFOS DEWS II pathophysiology report. Ocul. Surf., v.15, p.438-510, 2017.

CASTANHO, L.S.; MOREIRA, H.; RIBAS, C.A.P.M. et al. Transplante de glândulas salivares labiais no tratamento de olho seco em cães pela autoenxertia. Rev. Bras. Oftalmol., v.72, p.373378, 2013.

CHERRY, R.L.; SMITH, J.D.; BEN-SHLOMO, G. Canine oral mucosa evaluation as a potential autograft tissue for the treatment of unresponsive keratoconjunctivitis sicca. Vet. Ophthalmol., v.21, p.48-51, 2018.

DELLMANN, H.; BROWN, E.M. Histologia veterinária. Rio de Janeiro: Guanabara Koogan; 1982. 397p.

DODI, P.L. Immune-mediated keratoconjunctivitis sicca in dogs: current perspectives on management. Vet. Med. (Auckl). v.6, p.341-347, 2015.
GALVÃO, S.R.; CUNHA, D.N.Q.; DEL CARLO, R.J. et al. Morphological, morphometric and histochemical aspects of the labial salivary glands of dogs. Semin. Ciênc. Agrár., v.37, p.3079-3086, 2016.

GIULIANO, E.A. Diseases and surgery of the canine lacrimal secretory system. In: GELATT, K.N.; GILGER, B.C.; KERN, T.J. (Eds.). Veterinary ophthalmology. 5.ed. Ames, Iowa: Wiley-Blackwell, 2013. p.912-944.

KASWAN, R.; PAPPAS, C.J.R.; WALL, K.; HIRSH, S.G. Survey of canine tear deficiency in veterinary practice. Adv. Exp. Med. Biol., v.438, p.931-939, 1998

LAMKIN, I.D.; ZIMMERMAN, K.L.; SMITH FLEMING, K.M. et al. Osmolarity of basal and reflex tears of normal dogs. Vet. Ophthalmol., v.23, p.747-753, 2020.

LEE, H.B.; CHOI, H.J.; CHO, S.M. et al. Efficacy of HL036 versus Cyclosporine A in the treatment of naturally occurring canine keratoconjunctivitis sicca. Curr. Eye Res., v.43, p.889-895, 2018.

LEMP, M.A.; BRON, A.J.; BAUDOUIN, C. et al. Tear osmolarity in the diagnosis and management of dry eye disease. Am. J. Ophthalmol., v.151, p.792-798, 2011

LOURENÇO, A.M.; MEGRE, M.G.; DELGADO, E. Tear film osmolarity in atopic dogs with allergic conjunctivitis. Ocular Dis., 2017. Available in: www.smgebooks.com. Accessed in: 21 Apr. 2021.

MARQUES, D.L.; ALVES, M.; MODULO, C.M. et al. Osmolaridade lacrimal e superfície ocular em modelo de olho seco por toxicidade. Ver. Bras. Oftalmol., v.74, p.68-72, 2015.

MOORE, C.P.; MCHUGH, J.B., THORNE, J.G. et al. Effect of cyclosporine on conjunctival mucin in a canine keratoconjunctivitis sicca model. Investigative ophthalmology \& visual science, v. 42, n. 3, p. 653-659, 2001.

MOTTA, D.A.; YAMASAKI, L., SANCHES, O.C., et al. Comparação entre dois protocolos de tratamento de ceratoconjuntivite seca experimentalmente induzida em coelhos. Arquivo Brasileiro de Medicina Veterinária e Zootecnia, v. 66, p. 47-54, 2014. 
OLIVEIRA, J.K.; WILLIAMS, D.L.; BOLLMANN, C. et al. Comparative efficacy of topical oclacitinib $0.1 \%$ and tacrolimus $0.01 \%$ in canine keratoconjunctivitis sicca. Vet. Ophthalmol., v.5, p.633-643, 2019

POTVIN, R.; MAKARI, S.; RAPUANO, C.J. Tear film osmolarity and dry eye disease: a review of the literature. Clin. Ophthalmol., v.9, p.20392047, 2015.

ROSA, A.S.; PEREIRA, J.T.; BOTTEON, R.C.C.M. Obstrução do duto nasolacrimal com etil-cianoacrilato como adjuvante no tratamento da ceratoconjuntivite seca em cães. Rev. Bras. Med. Vet., v.34, p.353-360, 2012.

SCHREIBER， S.L.; CRABTREE， G.R. The mechanism of action of cyclosporin A and FK506. Immunol. Today, v.3, p.136-142, 1992.

SEBBAG, L.; ALLBAUGH, R.A.; WEHRMAN, R.F. et al. Fluorophotometric assessment of tear volume and turnover rate in healthy dogs and cats. J. Ocul. Pharmacol. Ther., v.35, p.497-502, 2019.

SEBBAG, L.; PARK, S.A.; KASS, P.H. et al. Assessment of tear film osmolarity using the TearLab ${ }^{\mathrm{TM}}$ osmometer in normal dogs and dogs with keratoconjunctivitis sicca. Vet. Ophthalmol., v.20, p.357-364, 2017.
SEBBAG, L.; KASS, P.H.; MAGGS, D.J. Reference values, intertest correlations, and testretest repeatability of selected tear film tests in healthy cats. J. Am. Vet. Med. Assoc., v.246, p.426-435, 2015.

SOARES, E.J.C.; FRANCA, V.P. Transplante de glândulas salivares labiais no tratamento do olho seco grave. Arq. Bras. Oftalmol., v.68, p.481-489, 2005.

SULLIVAN, B.D.; WHITMER, D.; NICHOLS, K.K. et al. An objective approach to dry eye disease severity. Invest. Ophthalmol. Vis. Sci., v.51, p.6125-6130, 2010.

WILLIAMS, D.L. Immunopathogenesis of keratoconjunctivitis sicca in the dog. Vet. Clin. North Am. Small Anim. Pract., v.38, p.251-268, 2008.

WILLIAMS, D.L.; BUCKINGHAM, A. Measurement of tear osmolarity in the canine eye: a new diagnostic tool for canine keratoconjunctivitis sicca. J. Vet. Sci., v.3, p.8-12, 2017.

YOON, A.; LIU, C.C.; CARTER, R.T. et al. Environmental relative humidity affects Schirmer tear test results in normal dogs. Vet. Ophthalmol., v.23, p.923-926, 2020. 